\title{
The Use Of The Mother Tongue In Saudi EFL Classrooms
}

\author{
Marzook M. Alshammari, College of Tourism and Hospitality, Madinah - Saudi Arabia
}

\begin{abstract}
The issue of including or excluding the learner's mother tongue in the EFL classroom has been the subject of ongoing discussion and controversy for a long time. This paper attempts to investigate the use of native Arabic in English classes at two Saudi technical colleges. The main objectives were to examine the purpose o L1 use and the attitudes of Saudi teachers and students towards the role of Arabic in the EFL classroom. Data were collected through two different types of questionnaires.

Results indicated that the use of Arabic (L1) was for clarification purposes and that a balanced and judicious use of $L 1$ in the EFL classroom by both teachers and students can be useful in the language learning process and may even be essential to increase learners' comprehension.
\end{abstract}

Keywords: Saudi EFL Classrooms; use of Mother Tongue; Attitudes

\section{INTRODUCTION}

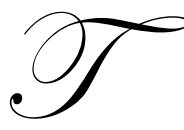

he issue of whether students' mother tongue should be used in the classroom has always been a subject of discussion by EFL researchers.

During the last three decades, a large and growing body of literature has investigated the role of the mother tongue in EFL classes. Auerbach (1993) for example, lists several different positive uses of L1 in L2 classrooms: these are classroom management, language analysis, presenting grammar rules, discussing cross-cultural issues, giving instructions or prompts, explaining errors, and checking for comprehension.

This view is supported by McCann (2005) and Cameron (2001) who suggest that translation can be used positively in a number of accessions such as explaining language structures, giving feedback, and maintaining classroom discipline.

Moreover, focus has been shifting towards inclusion of L1 in the language classroom: Nunan and Lamb (1996), for example, claimed that the exclusion of the mother tongue especially with monolingual students at lower English proficiency levels seems to be impossible.

In his Natural Approach to language acquisition, Krashen (1981) argues that students learning foreign languages generally follow the same strategic methods as they do in acquiring their mother tongues, and he maintains that the use of a student's first language in the classroom needs to be kept to the bare minimum.

Harbord (1992) points out that "many ELT teachers have tried to create English-only classrooms but have found they have failed to get the meaning across, leading to student incomprehension and resentment". He concludes, therefore, that "translation/transfer is a natural phenomenon and an inevitable part of second language acquisition regardless of whether or not the teacher offers 'permits' of translation".

Furthermore, Eldridge (1996) analyzed the code-switching of EFL young learners in a Turkish secondary school. The study showed that there was "no empirical evidence to support the notion that restricting mother tongue use would necessarily improve learning efficiency, and that the majority of code-switching in the classroom is 
highly purposeful, and related to pedagogical goals".

In another study of Spanish-speaking learners of English, Schweers (1999) investigated the validity of using L1 in EFL classrooms at a university level. He found that $88.7 \%$ of the students and $100 \%$ of the teachers in the study felt that Spanish should be used in their English classes. 86\% of the students felt that their L1 should be used to explain difficult concepts and $67 \%$ said that their L1 helped them to feel "less lost".

Tang (2002) conducted a similar study in China with Chinese speakers. The results indicated that L1 was used by the majority of the teachers participated, and that both students and teachers supported its use in the EFL classroom.

Cook (2001) suggested that L1 "can be deliberately and systematically used in the classroom" in different situations:

- $\quad$ "to provide a short-cut for giving instructions and explanations" where it is necessary

- $\quad$ "to build up the inter-linked L1 and L2 knowledge in the students' minds"

- $\quad$ "to carry out learning tasks through collaborative dialogue with fellow-students" and

- $\quad$ "to develop L2 activities such as code-switching for later real-life use"

He concluded that in the case of using the two languages, teachers can develop certain techniques to enhance the learning process once they feel that they "are free from their inhibitions about using the L1".

Although this body of literature on international students continues to grow, few studies have explored the issue from the perspective of the Saudi EFL classroom. Al-Abdan (1993) investigated the use of Arabic in EFL classroom in Saudi intermediate public schools. A total of 451 English teachers and supervisors responded to a questionnaire specifically designed to collect data about this issue. The results showed that $75 \%$ of these teachers use Arabic while teaching English for about $10 \%$ of the class time. Moreover, the study identified a number of factors that might encourage the use of L1 in English classes, such as the unavailability of teaching aids, the effort needed in teaching monolingual students and the shortage of time allotted to English in these schools.

Al-Nofaie (2010) ${ }^{1}$ examined the attitudes of teachers and students towards the use of Arabic in EFL classes in a Saudi intermediate girls' school. The participants were 30 students and three teachers of English. Three research tools were used for data gathering: questionnaires, interviews and classroom observations The results revealed that teachers and students generally had positive attitudes towards the use of Arabic in the classroom. The participants preferred to use Arabic with beginners and low-proficiency level students and for specific reasons: explaining grammatical terms, introducing new vocabulary and giving exam instructions.

Having been an EFL teacher for more than ten years, I feel that students prefer to use their mother tongue, especially when explaining new structural patterns, in order to have full information about the correct use of the language.

One criticism found in much of the literature on the use of L1 in L2 classes, however, is that students who learnt the target language in this way might be deficient in speaking as they would first begin to think in L1 and then translate their ideas into L2 (Shaikh, 1993; Richards and Rodgers, 2001). It is therefore likely that such thoughts may lead some EFL teachers to feel reluctant regarding the use of L1 in the classroom, even when it is necessary.

\section{PURPOSE OF THE STUDY}

Little attention has been paid to the issue of using L1 in the context of the Saudi EFL classroom, especially at the upper secondary school level. This motivated me to conduct further investigations to find out the views of Saudi teachers and students towards the use of Arabic in EFL classrooms at a college level. The study has been conducted in two technical colleges in Madinah region and included two main groups of teachers and students.

\footnotetext{
${ }^{1}$ http://www.novitasroyal.org/Vol_4_1/al-nofaie.pdf
} 


\section{RESEARCH QUESTIONS}

This study aims to answer the following questions:

1. What are the attitudes of the students and teachers towards the use of Arabic in the EFL classroom?

2. For what purposes do teachers use Arabic in the EFL classroom?

3. To what extent do both students and teachers think that the use of Arabic in the classroom is necessary?

\section{METHODOLOGY}

\section{Participants}

The participants in this study were 13 teachers and 95 students. All students were attending EFL classes as part of their training program at two Saudi technical colleges - the College of Technology and the College of Tourism - in Madinah region.

Student participants were taught English as a foreign language for six years at intermediate and secondary schools before joining the college programs. Their English proficiency was at pre-intermediate level.

\section{Methods and Procedures}

The study was built on two different types of written questionnaires. The first type was for students and asked a variety of questions related to their views on the use of Arabic in EFL classrooms. The second type was for EFL teachers, and asked questions about their attitudes towards the use of Arabic, and the different occasions when they think Arabic should be used in their EFL classrooms.

\section{RESULTS}

Questionnaires were distributed to 100 students and 18 teachers. Only 95 students and 13 teachers responded to the questionnaires. Tables 1 and 2 below summarize the percentages of participants' responses according to the questionnaires statements.

In general, the data collected revealed that the majority of students (61\%) and of teachers (69\%) believe that Arabic should be used in the English classroom.

Table1: Students views on the use of Arabic in the classroom

\begin{tabular}{|l|c|}
\hline \multicolumn{1}{|c|}{ Statements } & Percentage \\
\hline Should Arabic be used in the classroom? & 61 \\
Yes & 39 \\
No & 54.6 \\
\hline For what purposes do you think Arabic should be used in the EFL classroom? & 13 \\
$-\quad$ explaining new vocabulary words & 27 \\
$-\quad$ explaining grammar point & 5.4 \\
$-\quad$ giving instructions & 45.8 \\
\hline Why do you think Arabic is necessary in the classroom? & 37.2 \\
$-\quad$ to understand difficult ideas better & 17 \\
$-\quad$ to identify the meaning of new vocabulary words better & 21 \\
\hline Do you prefer your teacher to use Arabic in the classroom? & 54 \\
$-\quad$ always & 14.6 \\
\hline$\quad$ very rarely & 10.4 \\
\hline
\end{tabular}

As shown in table1, students indicated that Arabic was desired most to explain new vocabulary points (54.6\%) and to clarify difficult concepts (27\%). 
In explaining why they thought the use of Arabic is necessary in English classes, $45.8 \%$ of students pointed out that Arabic should be used to understand difficult ideas better, $37.2 \%$ indicated that Arabic should be used to identify the meaning of new vocabulary words better, and finally $17 \%$ thought that the use of the mother tongue helped them to feel comfortable and less stressed.

Around $90 \%$ of student participants stated that they preferred their teachers to use Arabic in English classes in some degree: $21 \%$ preferred Arabic 'always', 54\% 'sometimes', and 14.6\% 'very rarely'. A little more than 10\% of student participants preferred it if their teachers 'never' used Arabic in English classes.

Table2: Teachers' beliefs about the use of Arabic in the classroom

\begin{tabular}{|l|c|}
\hline \multicolumn{1}{|c|}{ Statements } & Percentage \\
\hline Should teachers use Arabic in the classroom? & 69 \\
Yes & 31 \\
N0 & 25.7 \\
\hline For what purposes do you think Arabic should be used in the EFL classroom? & 16 \\
$-\quad$ explaining new vocabulary words & 51 \\
$-\quad$ explaining grammar points & 7.3 \\
$-\quad$ clarifying difficult concepts or ideas & 24 \\
\hline$\quad$ giving instructions & 60.1 \\
\hline$\quad$ it increases comprehension & 15.9 \\
\hline
\end{tabular}

As for teachers, it is apparent from Table 2 that Arabic was most essential to clarify difficult concepts (51\%) and to explain new vocabulary words (25.7\%)and grammar points (16\%) .Only (7.3\%) reported that Arabic is useful for giving instructions.

When asked why they thought that Arabic was necessary in the class room, $60.1 \%$ of teachers indicated that Arabic helped them to reduce time spent, followed by $24 \%$ who felt that it was necessary to increase students comprehension. A minority of teachers (15.9\%) thought that the use of Arabic made the learning process more effective.

The results of the research show that the use of Arabic in the English classrooms is reasonable. It is mainly helpful to explain the meaning of new words, to explain grammar points, and to clarify difficult concepts. Teachers believe that the use of Arabic can save them time, enhance comprehension, and make the learning process more effective.

\section{DISCUSSION}

The results of the current study revealed that the mother tongue was used by the majority of teachers who participated, and it showed that both teachers and students had positive views towards L1 use in English classes. This finding seems to be consistent with those of Al-Nofaie (2010), Tang (2002) and Schweer (1999) which showed that both teachers and students responded positively towards the use of L1.

Based on my experience as an EFL teacher, I feel that students generally prefer teachers who use their L1 in the classroom. It seems possible that students have a tendency to use Arabic in the English classes because (a) they do not understand the teacher, (b) they do not know the answer, and (c) they cannot express their ideas in English.

Through my personal conversations with some EFL teachers I realized that many teachers would agree that a limited use of L1 is more efficient for achieving rapid understanding of L2. Some teachers have speculated that L1 use may help students to be aware of the similarities and variations between cultures and linguistic structures, and consequently could provide accurate translation (Cook, 2001). 
However, with EFL students, caution must be applied concerning the use of dictionaries in the classroom. The main difficulty with allowing students to translate words for each other relates to time efficiency as it sometimes takes more time to give everyone a chance to figure out the meaning.

One of the issues emerging from these findings is that learners who are forced to learn a new language may tend to overuse their L1 in order to stay within their area of comfort. It is recommended therefore that students should be taught common formulaic phrases associated with the classroom procedures early in the course. It may also be worthwhile for English teachers to discover more ways to create an environment in which students do not feel shy about committing mistakes in the target language.

\section{CONCLUSION}

This study has investigated the views of Saudi teachers and students towards the use of native Arabic in EFL classes. The most obvious finding to emerge from this study is that balanced and careful use of Arabic in the EFL classroom seems not to affect the students' exposure to the target language. It can even be useful in the learning process and may be needed for increasing comprehension.

The present study confirms previous research findings and contributes additional evidence which relates to the possibility of determining how much and when L1 is most useful for EFL students in the classroom.

Taken together, these results suggest that as a rule, the EFL teacher should only use L1 as a last resort in order to explain difficult grammar concepts and vocabulary items.

Further studies with similar topics need to be conducted with observation and interviews in other contexts in order to achieve a clearer understanding of what teachers and students believe about the use of L1 in the EFL classroom.

\section{AUTHOR INFORMATION}

Marzook Maazi Alshammari teaches English at the College of Tourism and Hospitality, Madinah - Saudi Arabia. E-mail:mmalsh2@yahoo.com

\section{REFERENCES}

1. Al-Abdan. A. (1993). A study on using Arabic in teaching English in Saudi intermediate schools. King Saud University Magazine, 50 (2), 396-426. Retrieved April 3, 2011, from: http://digital.library.ksu.edu.sa/paper2243.html

2. AL-Nofaie, H. (2010), The attitudes of teachers and students towards using Arabic In EFL classrooms in Saudi public schools - a case study. Novitas-ROYAL (Research on Youth and Language), 4 (1), 64-95. Retrieved March 12, 2011, from: http://www.novitasroyal.org/Vol 4 1/al-nofaie.pdf

3. Auerbach, E. (1993). Reexamining English only in the ESL classroom. TESOL Quarterly 27, (1), 9-32.

4. Cameron, L. (2001). Teaching languages to young learners. Cambridge: Cambridge University Press.

5. Cook, V., (2001). Using the first language in the classroom. Canadian Modern Language Review, 57(3), 402-423.

6. $\quad$ Eldridge, J. (1996). Code-switching in a Turkish secondary school. ELT Journal 50 (4),303-311.

7. Harbord, J. (1992). The use of the mother tongue in the classroom. ELT Journal, 46, 350-355.

8. Krashen, S. (1981). Second language acquisition and second language learning. Oxford: Pergamon.

9. McCann, K. (2005). Not lost in translation. IATEFL Issues, 186, p8.

10. Nunan, D. and Lamb, C. (1996). The self-directed teacher. Cambridge: Cambridge University Press.

11. Richards, J. C. and Rodgers, T.S, (2001). Approaches and methods in language teaching. New York: Cambridge University Press.

12. Schweers, W. Jr. (1999). Using L1 in the L2 classroom. English Teaching Forum, 37 (2), 6-9

13. Shaikh, A. (1993), Methods of teaching English as a foreign language: a comparative study of traditional and modern approaches. Lahore, Pakistan: Carvan Book House.

14. Tang, J. (2002). Using L1 in the English classroom. English Teaching Forum, 40 (1) 36-43 
Appendix A

Students' Questionnaire

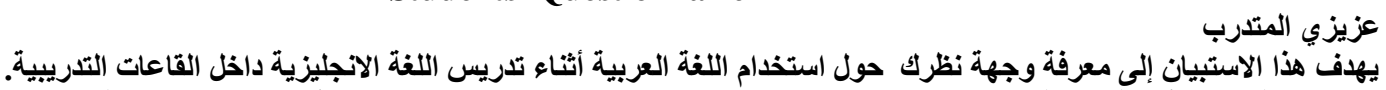

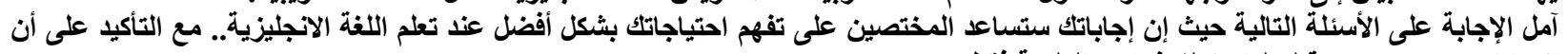
الإجابات ستستخدم من قبل الباحث للإغراض الإن العلمية فقط.

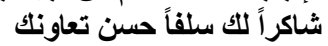

\begin{tabular}{|c|c|c|c|}
\hline Y & نعم & هل تؤيد وبثكل عام استخدام اللغة العربية أثناء تدريس اللغة الانجليزية داخل القاعة التدريبية ؟ & .1 \\
\hline & & 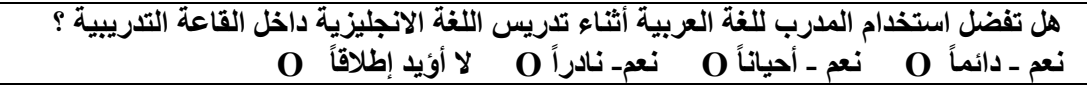 & .2 \\
\hline & & 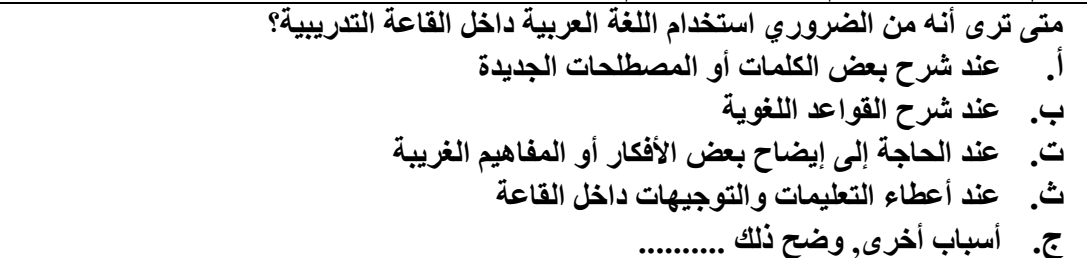 & .3 \\
\hline & & 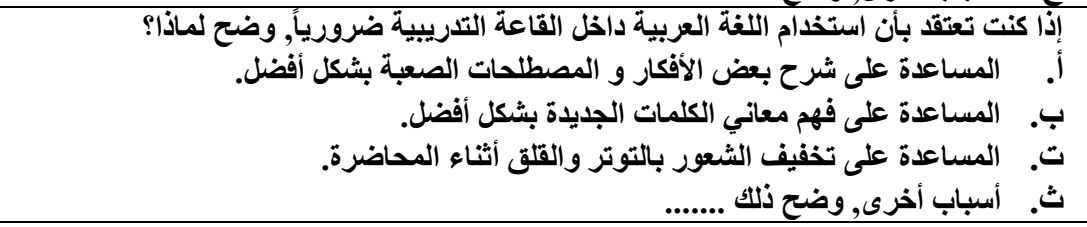 & .4 \\
\hline
\end{tabular}




\section{Appendix B}

\section{Teachers' Questionnaire}

Dear Colleague

This questionnaire aims to find out your attitude towards the use of Arabic in the English classroom.

Thank you for your cooperation!

1. Should teachers use Arabic in the classroom?

$$
\text { Yes }
$$

No

2. For what purposes do you think Arabic should be used in the EFL classroom?

(Multiple selection allowed)

a) explaining new vocabulary words

b) explaining grammar points

c) clarifying difficult concepts or ideas

d) other, please specify

3. Why do you think Arabic is necessary in the classroom? (Choose only one)

a) it increases comprehension

b) it reduces time consumed

c) it makes the learning process more effective

d) other, please specify ............ 


\section{NOTES}

